\title{
PERNIKAHAN DINI, PERCERAIAN, DAN PERNIKAHAN ULANG: SEBUAH TELAAH DALAM PERSPEKTIF SOSIOLOGI
}

\section{Suhadi $\bowtie$}

SMA Pamotan Rembang, Jawa Tengah, Indonesia

\section{Info Artikel}

Sejarah Artikel:

Diterima Juni 2012

Disetujui Juli 2012

Dipublikasikan September 2012

Keywords:

Early marriage;

Divorce;

Re-marriage;

Sociological perspective.

\begin{abstract}
Abstrak
Tujuan penelitian ini adalah untuk memetakan penelitian sosiologis dan antropologis tentang pernikahan dan perceraian dengan menggunakan perspektif komprehensif. Penelitian yang sudah ada tentang pernikahan dini, perceraian, dan pernikahan ulang dianalisi dan dikelompokkan dalam perpektif fungsional, perspektif konflik, dan perspektif interaksionisme simbolik ini.Penelitian dilakukan terhadap 12 judul penelitian pernikahan dini, 10 judul penelitian perceraian, dan 3 judul penelitian pernikahan ulang. Fenomena pernikahan dini, perceraian dan nikah ulang ternyata memiliki relasi kompleks terhadap kehidupan sosial. Relasi tersebut diantaranya; beragamnya realitas sosial yang melahirkan perceraian, perceraian untuk meraih kekuasaan, terdapat redefinisi bahwa perceraian itu pilihan rasional. Perpektif sosiologi yang sering digunakan dalam penelitian perkawinan dan perceraian adalah perspektif fungsional dan perspektif konflik, diperlukan kajian dengan pendekatan interaksionisme simbolik untuk menghasilkan nuansa baru dalam kajian perkawinan.
\end{abstract}

\begin{abstract}
The objective of this study is to map the existing sociological and anthropological researches about marriage and divorce using a comprehensive perspective. Existing research on early marriage, divorce, and remarriage are analyzed and grouped into functional perspective, conflict perspective and symbolic interactionist perspective. Twelve research reports on early marriage, 10 research titles on divorce and 3 titles on remarriage are analysed. The phenomenon of early marriage, divorce and re-marriage appears to have a complex relationship to social life. The relationship for exampple include the diverse factors that contribute to divorce, the use of divorce to gain power, the redefinition of divorce as rational choice and so on. Sociological perspective often used in the study of marriage and divorce is a functional and conflict perspective. It is necessary to study the symbolic interactionism approach to produce a new nuance in the study of marriage.
\end{abstract}

(C) 2012 Universitas Negeri Semarang

\footnotetext{
Alamat korespondensi:

SMA Pamotan Rembang 622562

E-mail: suhadi@gmail.com
} 


\section{PENDAHULUAN}

Fenomena pernikahan dini, perceraian, dan pernikahan ulang, hingga sekarang masih menjadi daya tarik untuk didiskusikan. Semua orang hampir dipastikan ingin sukses dalam menjalani proses pernikahan. Hampir dipastikan pula, semua orang tidak ingin mengalami ritual perceraian, terlebih pula perhelatan akan pernikahan ulang.

Namun kenyataannya tidak semua impian itu terwujud secara ideal. Hingga sekarang masih saja terjadi pernikahan dini, terpaan badai perceraian yang tak terhindarkan, hingga pernikahan berkali ulang dengan biaya sosial dan material yang cukup besar.

Kehadiran telaah pustaka tentang tiga fenomena sosial ini, diharapkan mampu menjadi informasi komprehensif tentang fenomena tersebut. Kajian ini tentu saja menjadi penting untuk melihat siapa melakukan penelitian apa, apa hasil dari penelitiannya, informasi apa yang dapat diformulasikan dalam penelitian berikutnya, hingga menstransformasikan dalam kekinian konteksnya.

\section{METODE PENELITIAN}

Kajian ini merupakan buah dari penelitian pustaka. Bahan kepustakaan yang digunakan adalah pustaka dalam bentuk skripsi, tesis, dan jurnal ilmiah yang telah dipublikasikan sebelumnya. Jenis dan jumlah pustaka yang digunakan yaitu; 12 judul penelitian pernikahan dini, 10 judul penelitian perceraian, dan 3 judul penelitian pernikahan ulang. Bahan kepustakaan dikumpulkan secara acak dari hasil kunjungan di lima perpustakaan di perguruan tinggi di Semarang, Salatiga, dan Yogyakarta tepatnya di kampus UGM, UKSW, UNDIP, dan UNIKA, dan UNNES pada tahun 2012.

Dasar konseptual yang digunakan dalam menganalisis dokumen terpilih adalah konsep yang telah disajikan oleh Henslin (2006) dengan tiga perangkat dasar instrumen. Instrumen pertama tentang analisis fungsional yang menitikberatkan pada struktur, fungsi (manifes dan laten), disfungsi, dan ekuilibrium. Instrumen kedua tentang perspektif interaksionisme simbolik yang menitikberatkan para penggunaan simbol, interaksi, makna, dan definisi. Instrumen ketiga tentang perspektif konflik yang menitikberatkan pada ketidaksetaraan, kekuasaan, konflik, persaingan, dan eksploitasi. Adapun model analisis yang digunakan adalah model deskriptif interpretatif.

\section{HASIL DAN PEMBAHASAN}

Secara umum penelitian terdahulu tentang fenomena pernikahan dini dapat dipetakan dalam empat temuan. Temuan pertama adalah pernikahan dini mampu membangun ikatan suci dalam membentuk keluarga harmoni sekaligus mampu meruntuhkan ikatan suci berkeluarga. Temuan kedua adalah pernikahan dini sebagai media meraih kuasa. Selanjutnya temuan ketiga adalah pernikahan dini sebagai simbol kemuliaan.

Peneliti sebagian besar masih meyakini bahwa pernikahan dini masih berfungsi dalam membangun ikatan suci dan harmoni. Hal ini dapat dilihat dengan temuan Sarwadi (2009) dimana pernikahan dini mampu membangun rasa setia dan keberkahan yang dipancarkan setelah terjadi jalinan pernikahan. Hal senada juga ditemukan oleh Rofidah dkk (2009; Rofidah, 2007) dimana pernikahan dini terbukti menciptakan sikap arif terhadap pasangan nikah yang ditunjukkan sikap menerima keadaan akan tingkat pendidikan, tingkat pekerjaan, dan keadaan ekonomi. Hal senada juga ditemukan Desmayanti (2009) dimana pernikahan dini berfungsi integratif akan tatanan harmonitas dalam keluarga.

Namun para pengikut yang meyakini bahwa pernikahan dini berfungsi membentuk keluarga bahagia ini, dibantah oleh para peneliti lainnya. Disfungsi pada pernikahan dini telah terbukti, dimana ditemukannya keluarga yang berantakan dalam menjalin tatanan yang harmoni.

Penelitian Pasaribu menyimpulkan terjadi banyak pasangan 
nikah yang meninggalkan tradisi pernikahan dini dengan alasan karena berbuah pada rumitnya menjalin keluarga harmoni. Calon pasangan nikah lebih suka melestarikan adat perkawinan lain yaitu menikah pada usia di atas batas yang telah mentradisi. Hal senada juga diungkap dalam penelitian Sativa (2009) yang menuding pernikahan dini hanya akan menjadi industri yang memproduksi perilaku sulit dalam menjalankan peran akan status baru hingga kemudian terbukti tidak harmonisnya rumah tangga.

Hal menarik untuk diikuti adalah temuan dari Shawky dan Milaat (2000) dimana pernikahan dini hanya menciptakan status buruh, keguguran saat kehamilan, hingga kematian janin dan kematian bayi. Hal tersebut sebenarnya telah diungkap jauh-jauh hari oleh Hanum (1997) dimana pernikahan dini hanya melahirkan resiko besar terhadap prognosa kehamilan yang berimplikasi terhadap kesehatan ibu dan anak, serta mempunyai beban psikologis pasangan yang bertubi-tubi.

Bantahan disfungsi keluarga harmoni pada pernikahan dini juga disampaikan Adhikari(1996)dengan penelitiannya tentang resiko dan konsekernsi dari pernikahan dini. Temuan Adhikari membuktikan bahwa pernikahan dini cenderung melahirkan kemiskinan struktural. Hal ini dapat dilihat, pascapernikahan pasangan cenderung tidak mampu mendapatkan pekerjaan yang layak sehingga berdampak pada rendahnya pendapatan dan kualitas pendidikan pada keluarganya.

Temuan kedua tentang pernikahan dini adalah media peraih kuasa. Jika penelitian sebelumnya memandang pernikahan dini telah berbuah fungsi dan disfungsi dalam tatanan keluarga, berbeda dengan penelitian berikut ini. Beberapa penelitian cenderung memberikan penjelas tentang mengapa terjadi pernikahan dini. Pergulatan akan kekuasaan dan pengendalian peran, menjadi tematik sentral dari beberapa temuan peneliti berikut ini.

Penelitian Hanum (1997) telah menjadi penegas bahwa pernikahan dini bukanlah pilihan dari pasangan pengantin. Faktor pengkondisianlah yang menjadi penentu dari perhelatan pernikahan dini. Kondisi seperti rendahnya akses pendidikan, kemiskinan penduduk, daerah yang terisolir, kelangkaan lapangan pekerjaan, serta rendanya mobilitas geografis dan sosial, telah mendorong terjadinya pernikahan dini. Jika kondisinya tidak demikian, tentu saja tidak terjadi pernikahan dini. Hanya saja Hanum tidak berani menegaskan siapa yang mengkondisikan situasi yang demikian itu.

Senada dengan Hanum, penelitian Muda (2008) juga menegaskan hal yang senada bahwa fenomena pernikahan dini bukanlah pilihan pasangan pengantin. Muda lebih fokus pada kajiannya tentang pergulatan dalam mendapatkan status sosial di suatu sistem sosial ketika terjadi pernikahan dini. Menurut Muda, anggota masyarakat yang memiliki akses untuk mendapatkan status sosial, cenderung segera melangsungkan pernikahan dini. Sebaliknya, mereka yang tidak memiliki relasi status sosial dalam sistem sosial cenderung menunda karena terpaksa. Berbagai aturan diciptakan agar menunda pernikahan mereka dengan cara mengenakan syarat yang rumit. Membawa barang-barang saat pernikahan berupa emas, perak, perhiasan, kain tenun, ternak, sebagai alat pertukaran untuk anggota masyarakat yang akan melangsungkan pernikahan dini. Jauh sebelum temuan Muda, pendapat Levistraus tentang perkawinan tampaknya masih relevan, dimana perkawinan merupakan persatuan antara pria dan pria dan yang dipertukarkan adalah perempuan (dalam Rahayaan, 2011) hingga terbentuknya kekerabatan-kekerabatan itu menitikberatkan pada siapa yang masuk dalam marga (dekat) dan siapa yang boleh mengawini siapa (marriage).

Suryaningrum (2009) pun demikian dalam menganalisis fenomena pernikahan dini. Dia menyimpulkan ada hubungan yang signifikan antara status ekonomi keluarga, pendidikan orang tua dan pekerjaannya terhadap anak-anaknya yang dinikahkan lebih dini.

Ketajaman dalam melihat fenomena pernikahan dini juga dilakukan oleh Wardhany (2009) dengan temuannya tentang kekuasaan sebagai kado spesial 
saat menikahi perempuan di bawah umur. Menurut Wardhany, dengan menikah, seseorang akan mendapatkan peran yang lebih dibanding peranan mereka sebelum menikah. Tanda mendapatkan kuasa saat menikah diantaranya; berperilaku agresif, berkepuasan, bebas meluapkan rasa jengkel, selalu menang sendiri, rasa menekan, dan luapan kemarahan. Semakin kompleks peran kuasa dari pasangan nikah, maka semakin berkuasa anggota pernikahan dalam mendapatkan kekuasaan.

Jika Wardhany menekankan kekuasaan, berbeda dengan Rohmah (2009) dengan temuannya bahwa pernikahan adalah suatu rasa kebebasan yang sebelumnya tidak didapatkan. Pernikahan dini dipandang sebagai hak sepenuhnya anak untuk mendapatkan pilihan sekaligus pelayan akan sebuah keinginan. Walaupun demikian, tradisi lama tetap memasung para pengikut pernikahan dini.

Pernikahan juga dimaknai sebagai perebutan kekuasaan. Hal ini dapat ditemui pada penelitiannya Rahayaan (2011) yang bertemakan tentang tapal batas pernikahan. Senada dengan Wardhany (2009), Rahayaan mampu mengungkap bahwa pernikahan dini ataupun pernikahan terlambat, memiliki relasi kuat dengan pelanggengan kekuasaan, budaya, dan pendidikan. Mereka yang terlambat nikah dijamin tidak akan mendapatkan kekuasaan, hak budaya, hingga hak pendidikan yang layak, atau bahkan terancam hilang dari eksistensi diri dalam bermasyarakat. Berbagai aturan komples diciptakan seperti larangan menikah beda agama, sebagai wujud syarat pertukaran yang sulit. Sebaliknya, memperbolehkan perkawinan lebih awal, semata-mata sebagai upaya mendapatkan kekuasaan dengan syarat pertukaran yang mudah. Relasi kuasa dan pernikahan juga dapat ditemukan dalam penelitiannya Suhadi (2010) pada masyarakat Baduy Dalam. Pernikahan endogami terjadi pada suku yang mendiami tinggal di pedalaman gunung Kendeng, Desa Kanekes, Kecamatan Leuwidamar, Kabupaten Lebak, Banten ini hanya dilakukan sesama suku Baduy Dalam. Jika meraka berani melakukan eksogami, mereka harus merelakan diri terhempas dari mandala (kawasan suci) ini, sekaligus merelakan perayaan hilangnya hak sosial dan budaya istimewa perihal pemilikan tanah adat, rumah, dan hingga upacara ritus hidup yang mampu menumbuhkembangkan emosi, moral, hingga ilmu kekebalan fisik.

Temuan ketiga adalah simbol kemuliaan yang terpancar pada fenomena pernikahan dini dapat dijumpai pada penelitian Leleury (2010) tentang reproduksi kemuliaan sebagai definisi akan ritual perkawinan. Leleury dalam penelitiannya tentang kewajiban perkawinan levirat menyimpulkan bahwa tujuan perkawinan adalah menghasilkan keturunan untuk meneruskan nama dari orang yang telah meninggal sehingga namanya tidak hilang.

Pernikahan ini juga berperan melanjutkan hak waris atas harta milik keluarga yang telah meninggal. Dengan demikian, pernikahan akan secepatnya dilakukan jika ada keinginan untuk mendapatkan status sosial atas sebagai simbol kemuliaan, hingga keberhasilan berinteraksi untuk mendapatkan keberlangsungan menjaga kemuliaan nama baik keluarga yang mendukung proses pernikahan.

Secara umum penelitian tentang perceraian ini dapat dipetakan dalam tiga hal. Pertama, relasi-relasi penyubur perceraian. Kedua, perceraian untuk mendapatkan kekuasaan. Ketiga, sebuah kabar baru tentang redefinisi perceraian.

Temuan faktor perceraian yang pertama adalah relasi penyubur perceraian. Penelitian Imariar (2010) membuktikan bahwa perkawinan pada usia dini memiliki relasi fungsi terhadap terjadinya perceraian. Masalah dalam keluarga baru, datang silih berganti seiring masa transisi yang begitu cepat. Perubahan status yang cukup cepat berdampak pada pasangan nikah tidak siap dalam menjalankan peran baru. Akibatnya adalah proses perceraian yang tidak terelakkan. Selanjutnya masalah yang mendera pasangan cerai ini semakin runcing dan serba sulit seiring dengan kesedihan yang harus dijalani dalam lingkungan sosial tanpa pasangan.

Namun penelitian Susanti (2009) 
membuktikan tidak adanya relasi fungsional antara pernikahan dini dengan terjadinya perceraian. Susanti menegaskan, perceraian semata-mata hanya dipengaruhi oleh pengangguran dari pasangan yang telah menikah. Susanti tidak hanya berhenti dalam hal perceraian saja. Susanti membuktikan bahwa pengangguran juga mempengaruhi rentang dan jumlah anak dari pasangan pernikahan.

Hal yang sama juga ditemukan dalam penelitian Bantulu (2008) tentang perceraian pada wanita yang bekerja dan berpendidikan. Bantulu menegaskan bahwa perceraian tidak disebabkan oleh pernikahan dini. Perceraian ditemukan pada pasangan pernikahan yang istrinya bekerja, berpendidikan, dan pengaruh dari dinamika transformasi budaya.

Hal tersebut senada dengan temuan Marhen (2009) tentang hubungan jenis kelamin dengan perceraian, dimana pernikahan dini tidak menjadi faktor pendorong terjadinya perceraian. Namun temuan Bantulu berbeda dengan Marhen. Ditegaskan bahwa laki-laki cenderung berpotensi aktif untuk menceraikan istri, hal ini bertolak belakang dengan temuan Bantulu.

Hal menarik dapat ditemui dari hasil penelitian Naniek (1999) tentang undangundang penyulut perceraian. Naniek menemukan relasi fungsi antara peraturan formal terhadap perceraian. Suasana suami dan istri cekcok, salah satu pihak berbuat zina, penjudi, dan tidak memberi nafkah, istri mandul, kekerasan dalam rumah tangga, hingga meninggalkan pasangan dari rumah, marak hadir setelah berlakunya Undang-Undang No. 1 Tahun 1974 tentang perkawinan.

Temuan penting Aryanti(2007)kembali meneguhkan bahwa gejala awal potensi terjadinya perceraian adalah selingkuh. Aryanti menegaskan, penyebab utama perselingkuhan adalah pengaruh teman. Aryanti menegaskan, kerap terjadi teman sepergaulan menciptakan strata kelas sosial dengan indikator berani selingkuh. Berani dan semakin rajin selingkuh, maka pelaku selingkuh itu semakin diterima menjadi anggota kelompok yang bersangkutan.

Temuan faktor perceraian yang kedua adalah perceraian untuk mendapatkan kekuasaan. Fenomena perceraian juga diulas secara kritis oleh Henslin (2006) dengan temuannya tentang pergeseran kekuasaan antara laki-laki perempuan pada fenomena perceraian. Henslin meyakini perceraian muncul karena adanya suatu pergeseran dalam kesetimbangan kekuasan antara kaum laki-laki dan kaum perempuan. Jika kaum laki-laki mengendalikan ekonomi, angka perceraian rendah karena kaum perempuan tidak mempunyai banyak alternatif terhadap pernikahan yang gagal. Menurut Hanslin, angka perceraian tinggi mencerminkan suatu pergeseran dalam kesetimbangan kekuasan antara kaum laki-laki dan kaum perempuan.

Hal senada juga diungkap Kusniti (tanpa tahun) dalam penelitiannya tentang tindakan meminggirkan hak perempuan untuk mendongkrak dominasi hak lakilaki dalam sistem sosial. Dengan adanya tradisi "perceraian bawah tangan", laki-laki seakan bebas tanpa batas dalam melakukan tindakan poligami dan kebal akan peraturan perundangan. Namun disisi lain, fenonema ini mengakibatkan terabaikannya hak perempuan dan anak dalam sistem keluarga.

Temua ketiga tentang faktor perceraian adalah tentang redefinisi perceraian. Penelitian menarik dilakukan Hasan (2007) dengan menyuguhkan tafsir perilaku cerai yang kemudian dilakukan secara bersamasama. Hasan menemukan dimana makna perceraian menunjukkan kecenderungan berbeda antara pemahaman suami dengan pemaknaan istri. Bagi suami, makna perceraian yaitu upaya mempertahankan harga diri di hadapan keluarga dan masyarakat, memutus penghambat kebebasan pribadi, solusi efektif untuk menyelesaikan masalah yang berkelanjutan, dan perceraian hanya sebatas perpisahan sementara saja. Sedangkan dipihak istri, memahami makna perceraian yaitu sebagai saluran pemuas emosi, melepaskan diri dari penderitaan, dan penebusan dosa akibat kegagalan saling menghargai.

Jika Hasan (2007) menitikberatkan terjadinya pernceraian pada makna 
yang dimiliki oleh pasangan suami dan istri, berbeda dengan Mau (2006) yang menitikberatkan pada industrialisme dan perubahan tren keluarga. Mau menegaskan, Industrialisme di satu sisi membawa perubahan sosial yang positif seperti kemajuan ilmu dan teknologi, namun disisi lain juga mendorong perubahan keluarga luas menjadi keluarga konjugal.

Pengenaan tafsir bersama untuk petunjuk bercerai juga ditemukan Oiladang (2008) tentang perceraian adalah tindakan rasional. Oiladang meyakini bahwa pilihan bercerai adalah tindakan yang didasarkan pada nilai adat. Rasionalisasi inilah menjadi dasar perceraian dalam kehidupan seharihari.

Ginting (2007) pun demikian, hanya saja lebih menekankan fenomena perceraian di bawah tangan yang sistemik. Ginting menunjukkan bahwa kebiasaan, adatistiadat, dan nilai-nilai hukum yang hidup dalam masyarakat, status dan kepentingan anak-anak yang lahir, serta surat keterangan perkawinan dari kepala desa, terbukti telah mendorong perilaku perceraian.

Selanjutnya penelitian tentang fenomena pernikahan ulang secara umum dapat dipetakan dalam dua pandangan. Pandangan pertama meyakini pernikahan ulang akan melahirkan gairah hidup harmoni dalam keluarga. Selanjutnya pandangan kedua meyakini pernikahan ulang berujung konflik dalam keluarga.

Temuan pertama tentang didapatkannya gairah hidup kembali dapat ditemui penelitian dari Isabella (2011) tentang fenomena pernikahan ulang. Isabella menandaskan, para perempuan menetapkan goal untuk mendapatkan pendamping hidup lagi yang dapat memberikan kebahagiaan. Perempuan yang memiliki anak usia kecil, berharap menikah lagi untuk memberikan sosok ayah untuk anaknya. Dukungan sosial, kepercayaan religius, dan kendali hidup, terbukti membantu mereka dalam mengembangkan harapan untuk menikah lagi.

Hal senada juga dibuktikan Sembiring (2009) dimana salah satu cara menghilangkan rasa takut yaitu dengan menikah ulang.
Sembiring menandaskan, ternyata tidak semua menikah ulang itu didominasi fungsi reproduksi.

Namun gairah hidup kedua yang didapatkan melalui pernikahan ulang, dibantah oleh Puspitawati dan Rossanda, sebagaimana menjadi temuan kedua tentang pernikahan ulang. Penelitian Puspitawati (2009) membuktikan terjadi hubungan yang penuh konflik terjadi dalam keluarga hasil pernikahan ulang. Peran yang dilembagakan oleh institusi keluarga, telah menciptakan pola relasi yang opresif.

Halsenadajuga diakuioleh Rossananda (2001) yang meneliti komunikasi adaptasi keluarga hasil menikah ulang. Rossananda menemukan beberapa hal menarik yaitu tentang pola adaptasi, pembagian peran, dan konflik.

Proses adaptasi yang terjadi dalam keluarga hasil menikah ulang yang dilakukan antara suami dengan istri, ayah dengan anak, ibu dengan anak, anak dengan anak, selalu mengalami kendala baik saat sebelum menikah maupun setelah menikah. Berikutnya, pembagian peran pada masingmasing pasangan nikah ulang tidak mampu berintegrasi. Selanjutnya, konflik yang terjadi dalam keluarga hasil menikah ulang merupakan kendala sejak tahap pendekatan sebelum menikah.

Berikut ini merupakan pemetaan penelitian terdahulu tentang fenomena pernikahan dini, perceraian, dan pernikahan ulang dengan telah menggunakan perspektif sosiologi. Pemetaan dilakukan guna mengetahui perspektif apa yang digunakan, seberapa dalam analisisnya, hingga apa fokus penelitian yang telah diulas dan yang belum di ulas oleh peneliti terdahulu ini. Dengan demikian, pemetaan perspektif pada penelitian terdahulu ini, dapat ditindaklanjuti oleh peneliti lanjutan yang tertarik pada tematik senada.

Berdasarkan ulasan penelitian terdahulu pada bagian atas dapat diketahui bahwa perspektif fungsional lebih dominan digunakan untuk analisis fenomena sosial. Delapan penelitian tentang fenomena pernikahan dini dapat dilihat pada tabel 1 berikut ini. 
Tabel 1. Pernikahan dini dengan perspektif fungsional

\begin{tabular}{|c|c|c|}
\hline Tahun & Peneliti & $\begin{array}{l}\text { Substansi } \\
\text { Penelitian }\end{array}$ \\
\hline 1997 & Hanum & $\begin{array}{l}\text { Masa depan } \\
\text { suram }\end{array}$ \\
\hline 2000 & $\begin{array}{l}\text { Shawky } \\
\text { dan Milaat }\end{array}$ & $\begin{array}{l}\text { Pembunuh janin } \\
\text { rahim }\end{array}$ \\
\hline 2007 & Rofidah & Kearifan hidup \\
\hline \multirow[t]{3}{*}{2009} & Sarwadi & $\begin{array}{l}\text { Kesetiaan dan } \\
\text { keberkahan }\end{array}$ \\
\hline & $\begin{array}{l}\text { Rofidah } \\
\text { dkk }\end{array}$ & $\begin{array}{l}\text { Jalinan keluarga } \\
\text { harmoni }\end{array}$ \\
\hline & Desmiyanti & $\begin{array}{l}\text { Integratif dan } \\
\text { harmonis }\end{array}$ \\
\hline \multirow[t]{2}{*}{2009} & Sativa & $\begin{array}{l}\text { Beratnya memikul } \\
\text { status ganda }\end{array}$ \\
\hline & Pasaribu & $\begin{array}{l}\text { Meruntuhkan } \\
\text { tradisi }\end{array}$ \\
\hline
\end{tabular}

Secara umum kedalaman analisis peneliti terdahulu tentang fenomena pernikahan dini dapat dikategorikan menjadi dua. Pertama pernikahan dini yang menciptakan keluarga bahagia. Kedua, pernikahan dini yang menciptakan keluarga berantakan.

Selanjutnya fokus penelitian yang telah di ulas pada peneliti terdahulu hanya sebatas analisis fungsi dan disfungsi. Adapun fokus penelitian yang belum di ulas adalah analisis struktur serta analisis ekuilibrium. Untuk itu para peneliti masa mendatang yang tertarik menggunakan perspektif fungsional, hendaknya menekankan pada analisis struktur dan ekuilibrium pada fenomena pernikahan dini. Selanjutnya perspektif fungsional juga masih digemari dalam meneliti fenomena perceraian. Pemetaan fenomena penelitian tersebut dapat dilihat pada tabel 2 .
Tabel 2. Perceraian dengan perspektif fungsional

\begin{tabular}{|c|c|c|}
\hline Tahun & Peneliti & Substansi penelitian \\
\hline 1999 & Naniek & $\begin{array}{l}\text { Undang-undang } \\
\text { penyulut perceraian }\end{array}$ \\
\hline 2004 & $\begin{array}{l}\text { Wirawan } \\
\text { dan arif }\end{array}$ & Paksaan perceraian \\
\hline 2008 & Bantulu & $\begin{array}{l}\text { Perempuan potensial } \\
\text { menceraikan suami }\end{array}$ \\
\hline 2009 & Marhen & $\begin{array}{l}\text { Laki-laki potensial } \\
\text { menceraikan istri }\end{array}$ \\
\hline 2010 & Imariar & $\begin{array}{l}\text { Perceraian akibat } \\
\text { perkawinan usia dini }\end{array}$ \\
\hline
\end{tabular}

Sumber: Diolah dari berbagai sumber

Kedalaman analisis yang dilakukan penelitian terdahulu tampak tidak mendalam. Analisis fungsional yang ditekankan hanya sebatas analisis relasi fungsi. Adapun penekanan pada analisis struktur, disfungsi, serta unsur ekuilibrium, masih langka ditemukan. Kelangkaan inilah yang nantinya perlu ditindaklanjuti para peneliti masa mendatang.

Tabel 3. Pernikahan ulang dengan perspektif fungsional

\begin{tabular}{lll}
\hline Tahun & Peneliti & $\begin{array}{l}\text { Substansi } \\
\text { penelitian }\end{array}$ \\
\hline 2001 & Rossananda & $\begin{array}{l}\text { Lika-liku } \\
\text { pernikahan ulang } \\
\text { dan tantangannya }\end{array}$ \\
2009 & Puspitawati & $\begin{array}{l}\text { Opresifitas } \\
\text { pernikahan ulang }\end{array}$ \\
& Sembiring & $\begin{array}{l}\text { Jalan terang } \\
\text { penghilang rasa } \\
\text { takut }\end{array}$ \\
\hline
\end{tabular}

Sumber: Diolah dari berbagai sumber 
Dibanding dengan penelitian pernikahan dini dan perceraian, penelitian pernikahan ulang cenderung jarang dipilih oleh peneliti terdahulu. Walaupun demikian, tematik penelitian ini cenderung mendekati tematik penelitian perkawinan secara umum.

Adapun penelitian yang sudah ada, perspektif fungsional yang digunakan hanya sebatas unsur fungsinya saja. Adapun unsur struktur, disfungsi, hingga unsur ekuilibriumnya, masih langka ditemukan.

Senada dengan penelitian perceraian, untuk itu peneliti masa mendatang yang menggunakan perspektif fungsional, diharapkan lebih fokus pada analisis unsur struktur, disfungsi, hingga unsur ekuilibriumnya.

Berdasarkan ulasan tentang fenomena penelitian terdahulu di atas, perspektif konflik juga menjadi pilihan kedua setelah perspektif fungsional dalam menganalisis fenomena pernikahan dini dan perceraian (lihat tabel 4). Hanya saja fenomena pernikahan ulang tampaknya tidak menjadi pilihan untuk teliti.

Kedalaman analisis pada pernikahan dini cukup menggembirakan. Beberapa unsur dalam perspektif konflik mendekati sempurna yaitu mulai dari unsur ketidaksetaraan, kekuasaan, konflik, hingga unsur persaingan. Hal ini dapat dilihat pada tabel 4. Walaupun demikian, analisis pada unsur eksploitasi masih langka ditemukan. Unsur eksploitasi memiliki ruang lingkup luas untuk ditindaklanjuti.

Ulasan lengkap tentang penelitian perceraian dapat dijumpai penelitiannya Hanslin. Sebuah telaah komprehensif telah dilakukannya. Model penelitian seperti itulah perlu dilakukan para peneliti di masa yang akan datang, sehingga unsur dalam perspektif konflik mulai dari unsur ketidaksetaraan, kekuasaan, konflik, persaingan, hingga unsur eksploitasi, mampu menyuguhkan gambaran lebih detail dan komprehensif.

Penggunakan perspektif interaksionis me simbolik dapat dilihat pada penelitian pernikahan dini dan penelitian tentang perceraian (lihat tabel 5). Perspektif ini masih jarang digunakan untuk penelitian fenomena pernikahan dini dan perceraian, terlebih pernikahan ulang. Perspektif yang menitikberatkan pada analisis tafsir ini akan bagaimana orang melakukan sesuatu bersama-sama ini, terkesan sulit lakukan.

Fokus penelitian dengan menitikberat kan pada unsur simbol, interaksi, makna, dan definisi terkesan belum populer pada penelitian terdahulu. Adapun yang telah digunakan dalam menganalisis fenomena pernikahan dini dan perceraian hanyalah pada sebatas unsur makna. Dengan demikian peluang untuk menggunakan perspektif ini

Tabel 4. Penelitian dengan perspektif konflik

\begin{tabular}{lll}
\hline Tahun & Peneliti & Substansi penelitian \\
\hline & & \multicolumn{1}{c}{ Pernikahan dini } \\
\hline 1997 & Hanum & Pernikahan adalah sebuah pengkondisian \\
2008 & Muda & Perkawinan sebagai skenario perebutan status sosial dan derajat \\
2009 & Suryaningrum & Perkawduduan yang dikendalikan \\
& Rohmah & Kebebasan semu dalam pernikahan \\
2010 & Suhadi & Endogami dan kompetisi kuasa budaya \\
2011 & Rahayaan & Tapal batas perkawinan \\
\hline & & \multicolumn{1}{c}{ Runtuhnya ikatan perkawinan } \\
\hline 2006 & Hanslin & Pergeseran harmoni kuasa laki-laki dan perempuan \\
2007 & Aryanti & Perselingkuhan penabuh perceraian \\
\hline
\end{tabular}

Sumber: Diolah dari berbagai sumber 
Tabel 5. Penelitian dengan perspektif interaksionisme simbolik

\begin{tabular}{lll}
\hline Tahun & Peneliti & Substansi penelitian \\
\hline \multirow{2}{*}{2010} & Lelleury & $\begin{array}{c}\text { Pernikahan dini } \\
\text { Reproduksi kemuliaan keluarga }\end{array}$ \\
\hline & \multicolumn{2}{c}{ Perceraian } \\
\hline 2006 & Mau & Industrialisasi biangkerok redefinisi ikatan suci \\
2007 & Hasan & Pergulatan kebenaran makna masing-masing \\
& Ginting & Perceraian yang sistemik \\
\hline
\end{tabular}

Sumber: Diolah dari berbagai sumber

masih terbuka lebar bagi para peneliti di dan pernikahan ulang.

masa mendatang.

\section{SIMPULAN}

Berdasarkan uraian di atas dapat ditarik simpulan sebagai berikut. Pertama, fenomena pernikahan dini memiliki relasi kompleks terhadap kehidupan sosial. Relasi tersebut diantaranya; mampu membangun keluarga harmoni, mampu meluluhlantakkan bangunan keluarga, sebagai media untuk mendapatkan kekuasaan, dan sebagai simbol kemuliaan sosial. Kedua, fenomena perceraianjuga memiliki relasi yangkompleks dalam kehidupan sosial. Relasi tersebut diantaranya; beragamnya realitas sosial yang melahirkan perceraian, perceraian untuk meraih kekuasaan, terdapat redefinisi bahwa perceraian itu pilihan rasional. Ketiga, fenomena pernikahan ulang telah memiliki relasi dalam kehidupan sosial. Relasi tersebut diantaranya; pernikahan ulang menumbuhkan kebahagiaan ulang, serta sekaligus sebagai sumber malapetaka pada keluarga hasil pernikahan ulang. Keempat, perpektif sosiologi yang sering digunakan dalam analisis masalah sosial adalah perspektif fungsional dan perspektif konflik, walaupun demikian, ketidaksempurnaan penggunaan unsur-unsur dalam perspektif tersebut relatif terjumpai.

Berdasarkan simpulan di atas, saran dalam penelitian ini yaitu hendaknya dalam menganalisis masalah sosial dengan pendekatan perspektif yang komprehensif, serta hendaknya dilakukan penelitian lanjutan tentang pernikahan dini, perceraian,

\section{DAFTAR PUSTAKA}

Adhikari, R.K. 1996. Early Marriage and Chilbearing: Risk and Consequences. http://who.int/repro ductive-health/.

Alimi, M.Y. 2012. Video Etnografi: Pengalaman Penelitian Sosial dengan Video Kamera di Sulawesi Selatan. Jurnal Komunitas. 4 (1): 41-50.

Aryanti, N.F. 2007. Fenomena Perselingkuhan dan Problem Solving Perselingkuhan Dalam Hubungan Pernikahan. Semarang: Universitas Katolik Soegijapranata. Fakultas Psiokologi.

Bantulu, Y. 2008. Perceraian di Amerika Serikat Pada Awal Abad ke-21. Yogyakarta: UGM. PPS Program Studi Pengkajian Amerika. Tesis.

Desmayanti. 2009. Hubungan Antara Resolusi Konflik dan Kepuasan Pernikahan Pada Pasangan Suami Istri Bekerja Pada Masa Awal Pernikahan. Jakarta: Fakultas Psikologi UI.

Ginting, F.H. 2007. Perceraian Dalam Perkawinan di Bawah Tengah (Studi Kasus di Pengadilan Negeri Kebanjahe. Yogyakarta: UGM.

Hanum, F. 2003. Pembagian Kekuasaan Suami-Istri Keluarga Jawa. Yogyakarta: UGM. Disertasi.

Hanum. 1997. Perkawinan Usia Belia. Kerjasama Pusat Penelitian Kependudukan Universitas Gajah Mada dengan Ford Foundation Yogyakarta. Yogyakarta: UGM.

Hasan, H. 2007. Perceraian Dalam Kehidupan Muslim Surabaya Jawa Timur: Studi tentang Makna Perceraian Dalam Perspektif Fenomenologis. Surabaya: Universitas Erlangga. Tesis.

Henslin, J.M. 2006. Sosiologi Dengan Pendekatan Membumi: Edisi 6. Penerj: Kamanto Sunarto. Jakarta: Erlangga.

Imariar, Cahaya Patri. 2010. Perceraian Pasangan Perkawinan Usia Dini. Salatiga: UKSW. FKIP. Skripsi.

Isabella, D. 2011. Harapan Menikah Lagi Pada Wanita Bercerai. Medan: Fakultas Psikologi Universitas Sumatera Utara. Skripsi.

Kustini. (tanpa tahun). Perceraian di Bawah Tangan: Potret Peminggiran Hak-hak Perempuan di 
Sukabumi. Jurnal Perempuan. 2 (1): 34.

Leleury, R. 2010. Kewajiban Perkawinan Levirat. Salatiga: Fakultas Teologi. UKSW.

Mau, Y.K. 2005. Perceraian dan Peran Single-Parent Perempuan. Semarang: Program Pascasarjana Universitas Diponegoro. Tesis.

Marhen, AG K.I. 2009. Sikap Terhadap Perceraian Ditinjau dari Tingkat Pendidikan, Jenis Kelamin dan Persepsi Pola Asuh Orang Tua. Yogyakarta: PPs UGM. Program Magister Psikologi. Tesis.

Muda, U.R. 2008. Dampak Perkawinan Adat Palangidi Pada Masyarakat Ankalang Kabupaten Sumba Tengah Terhadap Belis dan Hubungan Sosial. Salatiga: UKSW. Program Studi Sosiologi. Skripsi.

Naniek. 1999. Alasan-lasan Terjadinya Perceraian Setelah Berlakunya Undang-Undang No.1 tahun 1974 di Kabupaten Pati. Semarang: Universitas Katolik Soegijapranata. Fakultas Hukum.

Oiladang, C.S. 2008. Pilihan Rasionalitas KawinCerai: Antara Pertimbangan Adat dan Agama. Yogyakarta: PPs Sosiologi. UGM. Tesis.

Pasaribu, P.J. 2009. Perubahan Adat Perkawinan Pada Masyarakat Pakpak Kelasen: Studi Deskriptif di Desa Si Onom Hudon Toruan Kecamatan Parlilitan Kabupaten Humbang Hasundutan. Medan: Universitas Sumatra Utara. Skripsi.

Rahayaan, M.A. 2011. Perkawinan Beda Kasta. Salatiga: PPs. Sosiologi Agama. UKSW. Tesis.

Rofidah. 2007. Faktor-Faktor yang Berhubungan Dengan Pernikahan Usia Dini di Kabupaten Purworejo Jawa Tengah. Yogyakarta: PPs. UGM. Ilmu Kemasyarakatan. Fak. Kedokteran. Tesis.

Rofidah, E.O. dan Wahyuni, B. 2009. "Faktor-Faktor yang Berhubungan Dengan Pernikahan Usia Dini di Kabupaten Purworejo Jawa Tengah". Dalam Berita Kedokteran Masyarakat. 25 (2).
Rohmah, A.N. 2009. Perubahan Tradisi Ngemblok Pada Perkawinan Adat Jawa (Studi Kasus pada Masyarakat Nelayan di Kecamatan Kragan Kabupaten Rembang). Semarang: Skripsi. Pendidikan Sosiologi Antropologi. UNNES.

Rossanda, T. 2001. Komunikasi Adaptasi Keluarga Dalam Remarriage. Semarang: Skripsi. Fakultas Ilmu Sosial dan Ilmu Politik. Universitas Diponegoro.

Sativa, O. Pernikahan di Tengah Masa Kuliah. Surabaya: Skripsi. Universitas Erlangga.

Sarwadi, J. 2009. Hakikat Perkawinan Menurut Komunitas Kejawen Urip Sejati. Salatiga:. UKSW. Skripsi

Sembiring, I.M. 2009. Penyesuaian Pernikahan Kembali Pada Pria Lanjut Usia. Medan: USU. Skripsi.

Shawky S. \& Milaat W. 2000. Early Teenage Marriage And Subsequent Prenancy Outcame, East Mediterr Helth.

Suhadi. 2010. Etika Masyarakat Pedalaman Dalam Pembangunan. Dalam Ian Falk dkk Seminar Internasional. Semarang: Unnes. Fakultas Ilmu Sosial.

Susanti, E. 2009. Pengangguran dan Perilaku Keluarga di Kabupaten Gunungkidul Tahun 2004-2008. Yogyakarta: PPs. UGM. Fakultas Ekonomi dan Bisnis. Tesis.

Suryaningrum., M.A. 2009. Analisis Status Ekonomi Sebagai Salah Satu Faktor Risiko Pengambilan Keputusan Menikah Usia Dini Remaja Puteri di Kecamatan Nglipar Kabupaten Gunungkidul. Yogyakarta: PPs UGM. Fakultas Kedokteran. Tesis.

Wardhany, T. 2009. Konflik Perkawinan pada Istri Perwira Polisi yang Menikah pada Usia Muda. Semarang: Univeritas Katolik Soegijapranata. Fakultas Psikologi. 